\section{Tropical Journal of Pathology and Microbiology}

2020 Volume 6 Number 7 September-October

\title{
A retrospective study on histomorphological spectrum of ovarian lesions in a tertiary care hospital
}

\author{
Subashree K. ${ }^{1 *}{ }^{*}$, Ravindran S. ${ }^{2}$, Balaji S. ${ }^{3}$ \\ DOI: https://doi.org/10.17511/jopm.2020.i07.03 \\ 1* Subashree K., Assistant Professor, Department of Pathology, Sri Venkateshwaraa Medical College and Research Centre, Puducherry, \\ India. \\ 2 Sneha Ravindran, Post-graduate, Department of Pathology, Sri Venkateshwaraa Medical College and Research Centre, Puducherry, India. \\ 3 Balaji S., Post-graduate, Department of Pathology, Sri Venkateshwaraa Medical College and Research Centre, Puducherry, India.
}

Introduction: Gynecological morbidity is defined as any condition, disease, or dysfunction of the reproductive system which is not related to pregnancy, abortion, or childbirth. A significant number of ovarian lesions have been known to cause Gynecological morbidity among most females. With the increased use of screening modalities, ovarian lesions have increasingly been encountered for pathological analysis. It is important to evaluate the pattern of clinical presentation, corroborating with histological diagnosis. Purpose: The present study was carried out to evaluate the histomorphological spectrum of various ovarian lesions among women in Puducherry. Material and Methods: This retrospective study was conducted on 350 ovarian samples received for five years in the Department of Pathology, of our tertiary teaching hospital. Clinicopathological data were retrieved from the hospital records. The histomorphological analysis was reviewed and neoplastic and non-neoplastic ovarian lesions were segregated according to the World Health Organization classification. Results: Based on histology, the predominant ovarian lesions diagnosed were nonneoplastic conditions including simple and follicular cyst, corpus luteal cyst, corpus hemorrhagic cyst, and cystic follicles constituting $40.6 \%$ on the right side and $34 \%$ on the left side. Malignancy was predominant on the right side $(1.7 \%)$ while the same was $0.6 \%$ on the left side. Conclusion: The present study has identified that non-neoplastic lesions are more common in ovaries than neoplastic lesions and it has identified that serous cystadenomas are the most common ovarian neoplastic lesions.

Keywords: Histomorphological patterns, Ovarian lesion, Neoplastic lesions, Non-neoplastic lesions, Ovary

Corresponding Author

Subashree K., Assistant Professor, Department of Pathology, Sri Venkateshwaraa Medical College and Research Centre, Puducherry, India.

Email: subashree.dr@gmail.com

\section{How to Cite this Article}

Subashree K, Ravindran S, Balaji S. A retrospective study on histomorphological spectrum of ovarian lesions in a tertiary care hospital. Trop J Pathol Microbiol. 2020;6(7):430-436.

Available From

https://pathology.medresearch.in/index.php/jopm/ar ticle/view/488
To Browse

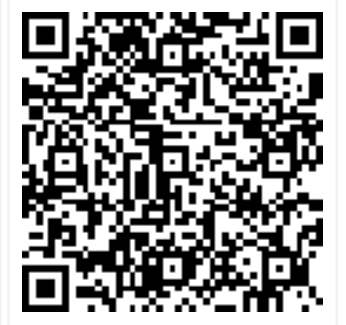

Manuscript Received 2020-10-05

Conflict of Interest No (c) 2020 by Subashree K., Sneha Ravindran, Balaji S. and Published by Siddharth Health Research and Social Welfare Society.
This is an Open Access article licensed under a Creative Commons Attribution 4.0 International License https://creativecommons.org/licenses/by/4.0/ unported [CC BY 4.0].
Review Round 2 2020-10-13

eview Round 2020-10-07

unding 


\section{Introduction}

In India, the health of women has been emphasized for many decades through various national health programs and policies. With a wide range of clinical manifestations and poor access to health care facilities, it is important to evaluate the pattern of clinical presentation, corroborating with histological diagnosis of ovarian lesions [1].

Ovaries are complex organs with unique physiology. The constant cyclical changes from puberty to menopause have made the ovary a site with a variety of cell types, each of which can give rise to tumors [2,3]. Though $80 \%$ of ovarian neoplasms are benign, the rest are malignant which causes significant mortality [4].

Malignant ovarian tumors represent the sixth most common cancer among females and the second most common cancer of the female reproductive system [5]. India has the 2nd highest burden of ovarian cancers with poor survival outcomes, demonstrating low survival after 5 years (29\%) [6].

Approximately $60-70 \%$ of the malignancies present as either stage III or stage IV disease $[7,8]$. The present study is undertaken to study the diverse histomorphological patterns of ovarian lesions in a medical college.

\section{Methodology}

Study setting: This retrospective study was conducted in the Department of Pathology, Sri Venkateshwaraa Medical College and Research Centre. All the clinicopathological data of ovarian samples, received from January 2016 to September 2020 were retrieved from the departmental records. The histomorphological analysis was reviewed, neoplastic and non-neoplastic ovarian lesions were segregated according to WorldHealth Organization classification [9]. A total of 350 specimens were evaluated in this study.

Selection criteria: All ovarian resection specimens (including cystectomy, oophorectomy specimens, and as a part of total abdominal hysterectomy (TAH) specimens) irrespective of the comorbid condition of the patients during surgery were included for the study.

Ethical approval and informed consent: Approval was obtained from the Institutional Ethics Committee before the commencement of the study.
Data analysis: Data was entered and analyzed using SPSS ver 15 software. The prevalence of gynecological morbidities was expressed as a percentage. A comparison of histological diagnosis with demographic data was carried out using the Chi-square test. A p-value $<0.05$ was considered statistically significant.

\section{Results}

The present study was carried out among 350 surgically resected ovarian specimens. The mean age of the participants was $42.7 \pm 8.5$ years. The majority of the participants were aged between 35 50 years $(70.3 \%)$.

The most common clinical diagnosis made was fibroid uterus $(50 \%)$ followed by cysts and tumors $(30.3 \%)$. The majority of the specimens were from total abdominal hysterectomy with bilateral salphingo-oophorectomy (76\%). (Table 1 ).

Table-1: Clinical particulars of the study participants.

\begin{tabular}{|c|c|c|}
\hline Characteristics & $\begin{array}{l}\text { Frequency } \\
\qquad(n=350)\end{array}$ & $\begin{array}{l}\text { Percentag } \\
\text { e (\%) }\end{array}$ \\
\hline \multicolumn{3}{|l|}{ Age (in years) } \\
\hline$<35$ & 63 & 18 \\
\hline $35-50$ & 246 & 70.3 \\
\hline$>50$ & 41 & 11.7 \\
\hline \multicolumn{3}{|l|}{ Clinical diagnosis } \\
\hline Bleeding abnormalities & 50 & 14.3 \\
\hline Uterine and ovarian mass (cyst/polyp/tumors) & 106 & 30.3 \\
\hline Fibroid/ adenomyosis & 175 & 50 \\
\hline Inflammatory diseases & 8 & 2.3 \\
\hline Prolapse uterus & 4 & 1.1 \\
\hline CIN/ endometrial hyperplasia & 7 & 2 \\
\hline \multicolumn{3}{|l|}{ Surgical procedure } \\
\hline $\begin{array}{l}\text { Total abdominal hysterectomy with bilateral } \\
\text { salphingo-oophorectomy }\end{array}$ & 266 & 76 \\
\hline $\begin{array}{l}\text { Total abdominal hysterectomy with unilateral } \\
\text { salphingo oophorectomy }\end{array}$ & 21 & 6 \\
\hline Bilateral salphingo-oophorectomy & 5 & 1.4 \\
\hline Unilateral salphingo oophorectomy & 28 & 8 \\
\hline Cystectomy & 29 & 8.3 \\
\hline Staging laparotomy & 1 & 0.3 \\
\hline
\end{tabular}

Based on histology, it was identified that irrespective of the laterality normal histology of ovaries including the presence of cortical inclusion cyst, corpus luteum, and corpus haemorrhagicum was more frequently encountered than other nonneoplastic and neoplastic lesions. 
The predominant ovarian lesions diagnosed were non-neoplastic conditions including simple and follicular cysts, corpus luteal cysts, corpus hemorrhagic cysts, and cystic follicles accounting for $40.6 \%$ on the right side and $34 \%$ on the left side (Table 2).

Table-2: Histopathological diagnosis among the study samples.

\begin{tabular}{|l|l|l|}
\hline \multicolumn{1}{|c|}{ Characteristics } & \multicolumn{1}{c|}{ Right N (\%) } & \multicolumn{1}{c|}{ Left N (\%) } \\
\hline Normal & $177(50.6)$ & $197(56.3)$ \\
\hline Non-neoplastic & $142(40.6)$ & $119(34)$ \\
\hline Benign & $23(6.6)$ & $31(8.9)$ \\
\hline Borderline & $2(0.6)$ & $1(0.3)$ \\
\hline Malignancy & $6(1.7)$ & $2(0.6)$ \\
\hline
\end{tabular}

The most common histomorphological diagnosis among the right lesions was follicular cyst including luteinized follicular cysts $(25.7 \%)$ followed by simple cyst $(10.9 \%)$ and corpus luteal cyst $(8 \%)$.

Among the left-sided lesions, the predominant ones include follicular cyst including luteinized follicular cyst $(20 \%)$ followed by simple cyst $(9.7 \%)$ and corpus luteal cyst (8.3\%) (Table 3) (Figure:1-4).

Table 3: Histological patterns in the ovary.

\begin{tabular}{|l|l|l|}
\hline \multicolumn{1}{|c|}{ Histological patterns in the ovary } & $\begin{array}{c}\text { Right N } \\
(\%)\end{array}$ & $\begin{array}{c}\text { Left N } \\
(\%)\end{array}$ \\
\hline $\begin{array}{l}\text { Normal, Cortical inclusion cyst Corpus } \\
\text { luteum, Corpushaemorrhagicum. }\end{array}$ & $140(40)$ & $\begin{array}{l}160 \\
(45.7)\end{array}$ \\
\hline Nonneoplastic & & \\
\hline Follicular cyst including luteinized follicular cyst & $90(25.7)$ & $77(22)$ \\
\hline Corpus hemorrhagic cyst & $8(2.3)$ & $8(2.3)$ \\
\hline Corpus luteal cyst & $29(8.3)$ & $29(8.3)$ \\
\hline Simple cyst & $38(10.9)$ & $34(9.7)$ \\
\hline Polycystic ovaries & $5(1.4)$ & $2(0.6)$ \\
\hline Endometriosis / endometriotic cyst & $4(1.1)$ & $6(1.7)$ \\
\hline Neoplastic & & \\
\hline Benign: & & \\
\hline Serous cystadenoma & $11(3.1)$ & $11(3.1)$ \\
\hline Serous cystadenofibroma & $1(0.3)$ & $3(0.9)$ \\
\hline Atypical proliferative serous tumor & $1(0.3)$ & $0(0)$ \\
\hline Mucinous cystadenoma & $2(0.6)$ & $4(1.1)$ \\
\hline Seromucinous cystadenoma & $2(0.6)$ & $2(0.6)$ \\
\hline Serous surface papilloma & $0(0)$ & $1(0.3)$ \\
\hline Brenner tumor & $2(0.6)$ & $3(0.9)$ \\
\hline Fibroma & $2(0.6)$ & $0(0)$ \\
\hline Mature Cystic teratoma & $4(1.1)$ & $5(1.4)$ \\
\hline Borderline & $1(0.3)$ & $1(0.3)$ \\
\hline Malignant: & $3(0.9)$ & $2(0.6)$ \\
\hline Serous cystadeno carcinoma & & \\
\hline
\end{tabular}

\begin{tabular}{|l|l|l|}
\hline $\begin{array}{l}\text { Mucinous cystadenoma with focal atypia and mural nodule } \\
\text { of anaplastic carcinoma }\end{array}$ & $0(0)$ & $1(0.3)$ \\
\hline Mucinous cystadenocarcinoma & $1(0.3)$ & $0(0)$ \\
\hline Seromucinous cystadenocarcinoma & $2(0.6)$ & $0(0)$ \\
\hline Clear cell carcinoma & $1(0.3)$ & $0(0)$ \\
\hline Granulosa cell tumor adult type & $0(0)$ & $1(0.3)$ \\
\hline
\end{tabular}

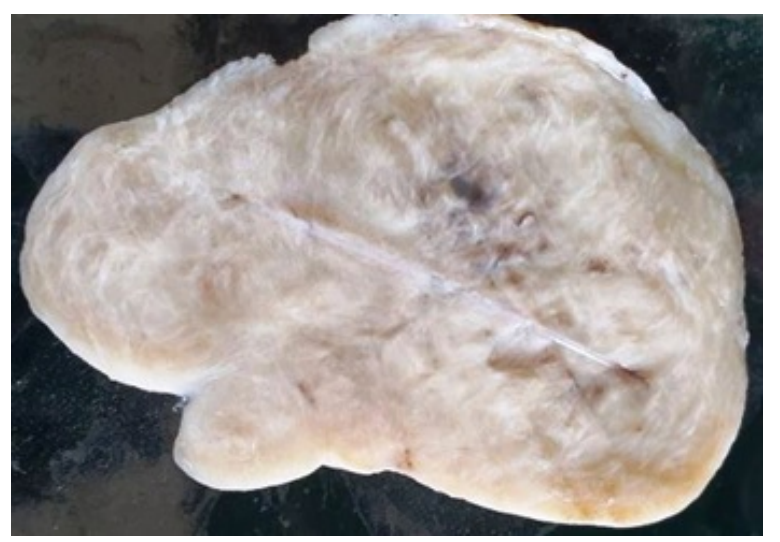

Fig-1: Ovarian fibroma. Grey white, firm mass with whorled cut surface.

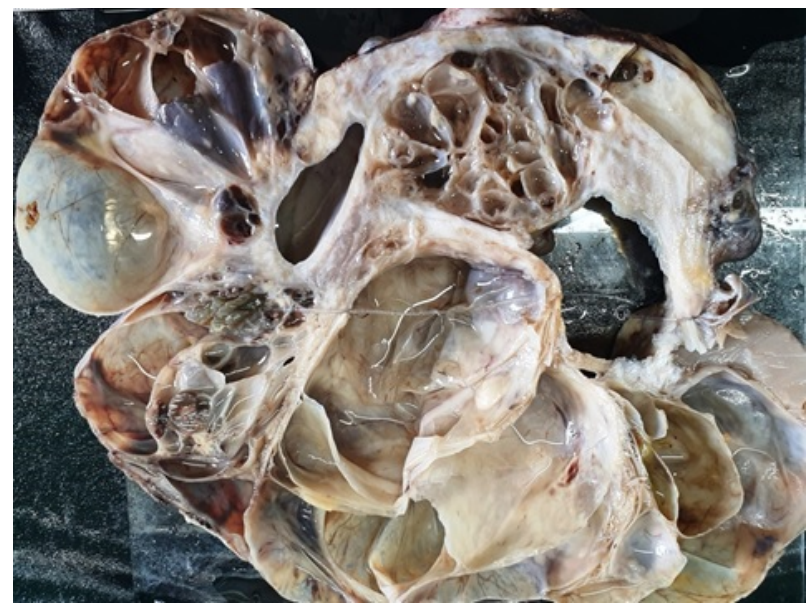

Fig-2: Seromucinous cystadenocarcinoma. Solid and cystic lesion with multiloculations.

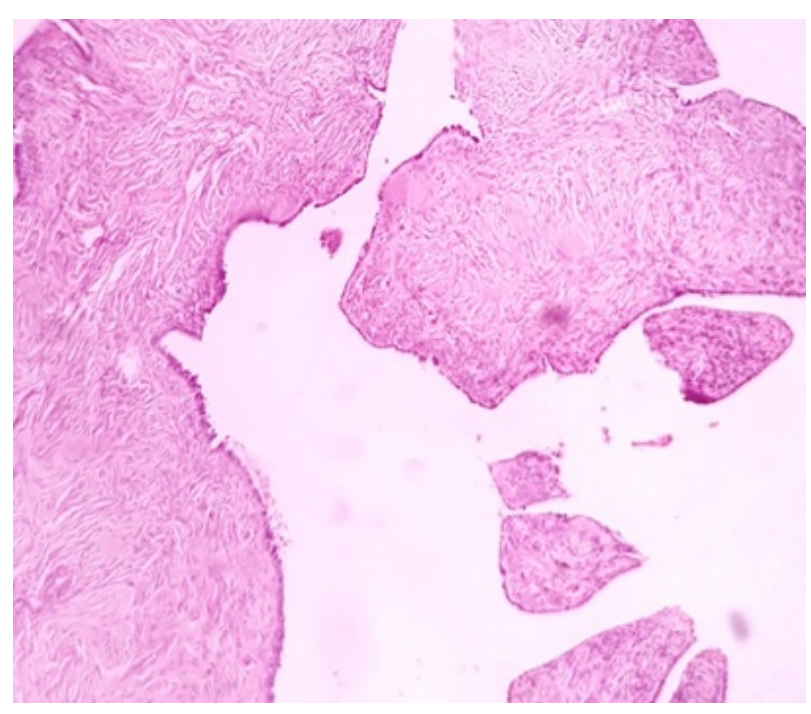


Fig-3: Serous cystadenofibroma. Broad fibrous papillae lined by serous lining epithelium (H and $E$ stain, 100X).

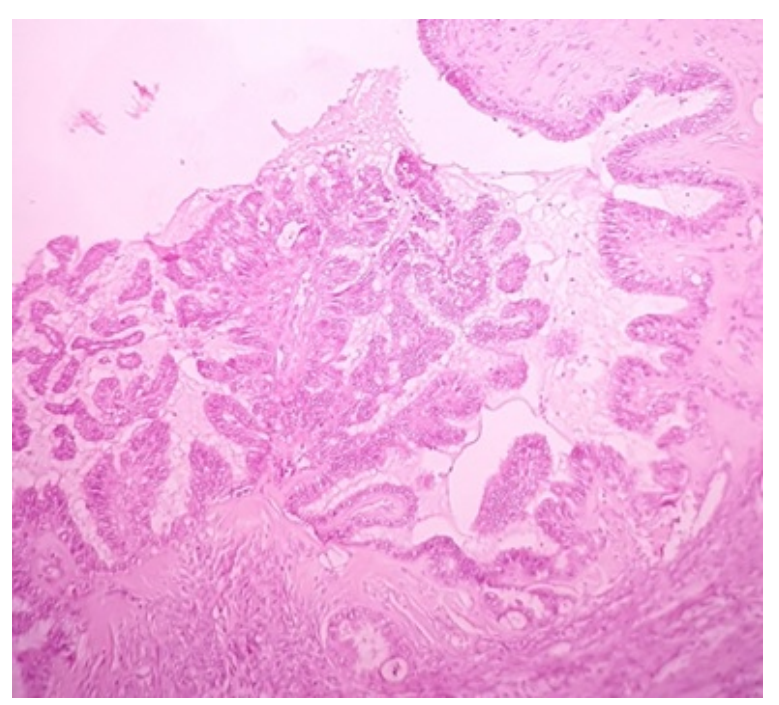

Fig-4: Serous Borderline tumor.Complex hierarchical branching pattern with no stromal invasion ( $H$ and $E$ stain, 100X).

Surface epithelial neoplasms were more common of which serious was the predominant type followed by mucinous tumors. (Table 4).

Table-4: Histological pattern of ovarian neoplasms according to WHO classification.

\begin{tabular}{|c|c|c|}
\hline $\begin{array}{l}\text { Histological patterns of ovarian neoplasms } \\
\text { according to WHO classification }\end{array}$ & $\begin{array}{l}\text { Right N } \\
(\%)^{*}\end{array}$ & $\begin{array}{l}\text { Left N } \\
(\%) *\end{array}$ \\
\hline \multicolumn{3}{|l|}{ Surface Epithelial tumors } \\
\hline Serous surface papilloma & $0(0)$ & $1(0.3)$ \\
\hline Serous cystadenoma & $11(3.1)$ & $11(3.1)$ \\
\hline Serous cystadenofibroma & $1(0.3)$ & $3(0.8)$ \\
\hline Atypical proliferative serous tumor & $1(0.3)$ & $0(0)$ \\
\hline Borderline serous tumor & $0(0)$ & $1(0.3)$ \\
\hline Serous cystadeno carcinoma & $3(0.8)$ & $2(0.5)$ \\
\hline Mucinous cystadenoma & $2(0.5)$ & $4(1.1)$ \\
\hline $\begin{array}{l}\text { Mucinous cystadenoma with focal atypia and mural } \\
\text { nodule of anaplastic carcinoma }\end{array}$ & $0(0)$ & $1(0.3)$ \\
\hline Mucinous cystadenocarcinoma & $1(0.3)$ & $0(0)$ \\
\hline Seromucinous cystadenoma & $2(0.5)$ & $2(0.5)$ \\
\hline Seromucinous cystadenocarcinoma & $2(0.5)$ & $0(0)$ \\
\hline Clear cell carcinoma & $1(0.3)$ & $0(0)$ \\
\hline Brenner tumor & $2(0.5)$ & $3(0.8)$ \\
\hline \multicolumn{3}{|l|}{ Sex cord-stromal tumor } \\
\hline Fibroma & $2(0.5)$ & $0(0)$ \\
\hline Granulosa cell tumor adult type & $0(0)$ & $1(0.3)$ \\
\hline \multicolumn{3}{|l|}{ Germ cell tumor } \\
\hline Mature Cystic teratoma & $4(1.1)$ & $5(1.4)$ \\
\hline
\end{tabular}

*Percentage will not total to 100.

In this study, the majority of ovarian neoplasms were benignly followed by malignant and borderline tumors. Serous cystadenomas $(3.1 \%)$ followed by mature cystic teratoma(1.4\%) were more common. In malignant tumors surface, epithelial tumors were more common in which serous type is more predominant $\quad(0.5 \%$ for serous cystadenocarcinoma). Malignancy was predominant on the right side $(1.7 \%)$ while the same was $0.6 \%$ on the left side.

Among the factors predicting the risk of right-sided lesions, in the age group of $<35$ years, nonneoplastic lesions constituted $38.1 \%$ while in the age group of 35-5 years, the same constituted $45.1 \%$. However, beyond 50 years of age, nonneoplastic lesions comprised $17.1 \%$ of the lesions. The observed difference was statistically significant $(p<0.0001)$ (Table 5).

Table-5: Factors predicting the risk of rightsided lesions.

\begin{tabular}{|c|c|c|c|c|c|c|c|c|}
\hline \multirow[t]{2}{*}{ Factors } & \multirow[t]{2}{*}{$\mathrm{N}$} & \multicolumn{5}{|c|}{ Histopathological diagnosis } & \multirow{2}{*}{$\begin{array}{l}\mathrm{Chi} \\
\mathrm{sq}\end{array}$} & \multirow{2}{*}{$\mid \begin{array}{c}P \\
\text { value }\end{array}$} \\
\hline & & Normal & $\begin{array}{l}\text { Non- } \\
\text { neoplastic }\end{array}$ & Benign & $\begin{array}{l}\text { Borderli } \\
\text { ne }\end{array}$ & $\begin{array}{l}\text { Malignan } \\
\text { cy }\end{array}$ & & \\
\hline \multicolumn{9}{|c|}{ Age (in years) } \\
\hline$<35$ & 63 & $\begin{array}{l}26 \\
(41.3)\end{array}$ & 24 (38.1) & $\begin{array}{l}11 \\
(17.5)\end{array}$ & $1(1.6)$ & $1(1.6)$ & \multirow[t]{3}{*}{37.6} & \multirow[t]{3}{*}{0.0001} \\
\hline $35-50$ & 24 & $\begin{array}{l}124 \\
(50.4)\end{array}$ & $111(45.1)$ & $6(2.4)$ & $0(0)$ & $5(2.0)$ & & \\
\hline$>50$ & 41 & $\begin{array}{l}27 \\
(65.9)\end{array}$ & $7(17.1)$ & $\begin{array}{l}6 \\
(14.6)\end{array}$ & $1(2.4)$ & $0(0)$ & & \\
\hline
\end{tabular}

Among the factors predicting the risk of left-sided lesions, in the age group of $<35$ years, nonneoplastic lesions constituted $28.6 \%$ while in the age group of $35-50$ years, the same constituted $37.4 \%$.

Table-6: Factors predicting the risk of leftsided lesions.

\begin{tabular}{|c|c|c|c|c|c|c|c|c|}
\hline \multirow{2}{*}{\multicolumn{2}{|c|}{ Factors }} & \multicolumn{5}{|c|}{ Histopathological diagnosis } & \multirow{2}{*}{$\begin{array}{l}\text { Chi } \\
\text { sq }\end{array}$} & \multirow{2}{*}{$\begin{array}{c}\mathrm{P}- \\
\text { value }\end{array}$} \\
\hline & & Normal & $\begin{array}{l}\text { Non- } \\
\text { neoplastic }\end{array}$ & Benign & $\begin{array}{l}\text { Borderli } \\
\text { ne }\end{array}$ & $\begin{array}{l}\text { Malignan } \\
\text { cy }\end{array}$ & & \\
\hline \multicolumn{9}{|c|}{ Age (in years) } \\
\hline$<35$ & 63 & $\begin{array}{l}33 \\
(52.4)\end{array}$ & $18(28.6)$ & $\begin{array}{l}11 \\
(17.5)\end{array}$ & $1(1.6)$ & $0(0)$ & \multirow[t]{3}{*}{23.7} & \multirow[t]{3}{*}{0.0001} \\
\hline $35-50$ & $\begin{array}{l}24 \\
6\end{array}$ & $\mid \begin{array}{l}140 \\
(56.9)\end{array}$ & $92(37.4)$ & $\begin{array}{l}12 \\
(4.9)\end{array}$ & $0(0)$ & $2(0.8)$ & & \\
\hline$>50$ & 41 & $\begin{array}{l}24 \\
(58.5)\end{array}$ & $9(22)$ & $\begin{array}{l}8 \\
(19.5)\end{array}$ & $0(0)$ & $0(0)$ & & \\
\hline
\end{tabular}


However, beyond 50 years of age, non-neoplastic lesions comprised $22 \%$ of the lesions. The observed difference was statistically significant $(p<0.0001)$ (Table 6).

\section{Discussion}

The mean age of the study participants in the present study was 42 years. The predominant age in which gynecological morbidity is encountered is beyond 35 years of age. Therefore, the ideal age for early intervention should ideally begin from 35 years of age.

In a meta-analysis and systematic review done by Dheresa $M$ et al, $51 \%$ of the morbidities were encountered in the age group between 35-49 years, similar to the present study findings [10].

Another study done by Puri $S$ et al to evaluate the epidemiology of ovarian cancers reported $48.3 \%$ of ovarian cancers in the age group of 40-59 years, similar to the present study [6].

The most common clinical diagnosis made on the study participants was fibroid uterus $50 \%$ followed by abdominal mass (30.3\%). Uterine fibroids are a commonly encountered gynecological morbidity, accounting for $20 \%-40 \%$ of all the gynecological problems in the reproductive age [8].

According to a study done by Shekhar $\mathrm{C}$ et al, the indication for $20 \%$ of hysterectomies done in India is due to uterine fibroids [10].

In this study, it was identified that irrespective of the laterality, normal histology of ovaries including the presence of cortical inclusion cyst, corpus luteum, and corpus haemorrhagicum was more frequently encountered than other non-neoplastic and neoplastic lesions in surgically resected specimens.

This is in contrast with the study done by Amin S Metal wherein the most commonly encountered ovarian morphology was non-neoplastic lesions [11].

The most commonly encountered ovarian lesions were non-neoplastic. The most frequently encountered non-neoplastic lesion on right and left side ovaries were follicular cysts (26\% and $22 \%$ respectively) followed by simple ovarian cyst ( $11 \%$ and $10 \%$ respectively), corpus luteal cyst $(8.3 \%$ each).
This is in concordance with the study conducted by Amin SM et al [11], wherein the most common presentation was non-neoplastic lesions with follicular cyst being the most common neoplastic lesion followed by corpus hemorrhagic cyst. But the finding where in contrast with the studies conducted by Thirukumar $M$ et al and Prakash $A$ et al wherein neoplastic lesions constituted the major bulk of ovarian lesions $[3,12]$.

According to the WHO classification of tumors, Surface epithelial neoplasms were more common, which is also the case in this study. Among surface epithelial neoplasms serous tumors are more common followed by mucinous tumors. In this study, the majority of ovarian neoplasms were benignly followed by malignant and borderline tumors. This finding is in concordance with Thirukumar $M$ et al AminSMetalandPrakash Aet al, Sharma P et al, Fatima Ret al.[3,11-14]

In the benign neoplasms, Serous cystadenomas followed by mature cystic teratoma were more common. Though Serous cystadenomas are the most common ovarian serous tumors, the most common neoplasm of the ovary is a cystic mature teratoma.[15,16]

However, the findings in this study are in concordance with the studies conducted by Sharma $\mathrm{P}$ et al, Fatima $\mathrm{R}$ et al, and Garg $\mathrm{N}$ et al, wherein serous cystadenomas followed by Mature cystic teratomas were more common.[13,14,17]

\section{Conclusion}

Since gynecological morbidities are rampantly on the rise in Indian women, there is an imminent need for evaluation of the epidemiological pattern based on histological confirmation.

\section{What does the study add to the existing knowledge}

The present study has identified an increase in the prevalence of non-neoplastic lesions. Most of the neoplastic lesions were Surface epithelial tumors in which serous tumors are more common. There is a shift in trend from the most common benign tumor from Mature cystic teratoma to Serous cystadenoma. Although newer techniques like immunohistochemistry and molecular analysis have been used histopathological analysis has not lost its sheen and is still the gold standard for diagnosing ovarian tumors. 


\section{Author's contribution}

Dr. K. Subashree: Concept, study design

Dr. Sneha Ravindran: Manuscript preparation and data analysis

Dr. S. Balaji: Manuscript preparation and data analysis

\section{Reference}

01. Brown J, Frumovitz M. Mucinous tumors of the ovary- Current thoughts on diagnosis and management. Curr Oncol Rep. 2014;16(6)389.

doi: $\quad 10.1007 / s 11912-014-0389-x \quad$ [Crossref]

02. Marques P, Skorupskaite K, George JT, Anderson RA. Physiology of GNRH and gonadotropin secretion. Endotext.

[Crossref]

03. Cui J, Shen Y, Li R. Estrogen synthesis and signaling pathways during ageing from periphery to brain. Trends Mol Med. 2013;19(3)197-209.

doi: 10.1016/j.molmed.2012.12.007 [Crossref]

04. Thirukumar M, Ahilan S. Histopathological pattern of ovarian lesions- a Hospital based study in Batticaloa, Sri Lanka. J Diagnos Pathol. 2018;13(1)16-21.

doi: $10.4038 /$ jdp.v13i1.7736 [Crossref]

05. National Cancer Institute 2005. SEER cancer statistics review (1975-2002). Ovarian epithelial cancer (PDG)- Treatment health professionals. Available at https://seer.

cancer.gov/csr/1975_2017/] [Crossref]

06. Puri S, Chadha V, Pandey AK. Epidemiology of ovarian tumors in North India - A tertiary hospital-based study. Indian J Comm Fam Med. 2018;4(2)37-41.

doi: $10.4103 / 2395-2113.251437$ [Crossref]

07. Pradhan A, Sinha AK, Upreti D. Histopathological patterns of ovarian tumours at BPKIHS. Health Renaissance. 2012;10(2)87-89.

doi: $10.3126 /$ hren.v10i2.6570 [Crossref]
08. Vaddatti T, Reddy ES, Vahini G. Study of morphological patterns of ovarian neoplasms. IOSR Journal of Dental and Medical Sciences. 2013;10(3)12-20. Available at:

[Article] [Crossref]

09. Longacre TA, Bell DA, Malpica A, Prat J, Ronnett BM, Seidman JD. WHO Classification of Tumors of the Ovary, In- Kurman RJ, Carcanglu ML, Herrington CS, Young $\mathrm{RH}$, editors. WHO Classification of tumors of female reproductive organs, 4th ed. Lyon- IARC. 2014;12-101. Available at [Article] [Crossref]

10. Dheresa M, Assefa N, Berhane $Y$, Worku A, Mingiste $B$, Dessie Y. Gynecological Morbidity among women in Reproductive Age- A Systematic Review and Meta-Analysis. J Women's Health Care. 2017;6;3.

doi: 10.4172/2167-0420.1000367 [Crossref]

11. Amin SM, Olah F, Babandi RM, Liman MI, Abubakar SJ. Histopathological analysis and clinical correlations of ovarianlesions in a tertiary hospital in Nigeria- A 10-year review. Ann Trop Pathol. 2017;8;25-28.

doi: 10.4103/atp.atp_16_17 [Crossref]

12. Prakash A, Chinthakindi $S$, Duraiswami $R$, Indira V. VI- Histopathological study of ovarian lesions in a tertiary care center in Hyderabad, India- a retrospective five-year study. Int J Adv Med. $2017 ; 4(3) 745$.

doi: 10.18203/2349-3933.ijam20172265 [Crossref]

13. Sharma P, Bharadwaj S. Histomorphological Spe ctrum of Ovarian Tumours in a Tertiary Care Ce ntre in North India. JMSCR. 2017;7(10)841-5. doi: $10.18535 / \mathrm{jmscr} / \mathrm{v} 7 \mathrm{i} 10.143$ [Crossref]

14. Fatima R, Sandhya M, Sowmya TS. Study of histomorphological pattern of ovarian neoplastic and non-neoplastic lesions. Int J Res Med Sci. 2017;5(5)2095-2098.

doi: $10.18203 / 2320-6012 . i j r m s 20171849$ [Crossref]

15. Seidman JD, Cho KR, Ronnett BM, Kurman RJ. Surface epithelial tumors of the ovary, InKurman RJ, Ellenson, LH, Ronnett BM, editors, Blaustein's pathology of the female genital tract, 6 th ed. New York- Springer. 2011;703.

[Crossref] 
16. Zaloudek CJ, Garg K. Tumors of the Female Genital Tract, 4th ed. Philadelphia- Elseviers. 2013.

[Crossref]
17. Garg N, Anand AS, Annigeri C. Study of histomorphological spectrum of ovarian tumours. Int J Med Health Res. 2017;3(10)1220.

[Crossref] 